\title{
Membrane and Synaptic Actions of Halothane on Rat Hippocampal Pyramidal Neurons and Inhibitory Interneurons
}

\author{
Koh-ichi Nishikawa and M. Bruce Maclver \\ Neuropharmacology Laboratory, Department of Anesthesia, Stanford University School of Medicine, Stanford, California \\ 94305-5117
}

\begin{abstract}
A relatively small number of inhibitory interneurons can control the excitability and synchronization of large numbers of pyramidal neurons in hippocampus and other cortical regions. Thus, anesthetic modulation of interneurons could play an important role during anesthesia. The aim of this study was to investigate effects of a general anesthetic, halothane, on membrane and synaptic properties of rat hippocampal interneurons. GABA receptor-mediated IPSCs were recorded with whole-cell patchclamp techniques in visually identified CA1 pyramidal cells and interneurons located at the border of stratum lacunosummoleculare and stratum radiatum. Halothane $(0.35 \mathrm{~mm} \cong 1.2$ vol\%) depressed evoked IPSC amplitudes recorded from both pyramidal cells and inhibitory interneurons. Also, halothane considerably prolonged the decay time constant of evoked IPSCs in pyramidal cells and interneurons. The frequencies of miniature
\end{abstract}

Depressed neuronal excitability is known to be associated with general anesthesia and is believed to result, at least in part, from enhanced GABA receptor-mediated synaptic inhibition. This inhibition may be either a feedforward type that functions to suppress other competitive forms of excitation or a feedback type that limits neuronal discharge activity. In the hippocampus, GABAergic inhibitory interneurons comprise $<10 \%$ of the total neuron population (Olbrich and Braak, 1985); however, small numbers of fastspiking local circuit interneurons control the excitability of thousands of pyramidal cells through divergent inhibitory connections. Thus, inhibitory interneurons could play an important role in regulating the excitability and synchronization of neural activity of hippocampus (Freund and Buzsaki, 1996) and other cortical regions during general anesthesia. Understanding how anesthetics affect GABAergic interneurons is important for an understanding of anesthetic actions in brain circuitry.

The finding that anesthetics enhance synaptic inhibition was first demonstrated by Nicoll (1972), who showed that pentobarbital prolonged the time course of IPSPs. Many studies have confirmed that anesthetics prolong the decay phase of $\mathrm{GABA}_{\mathrm{A}}$ receptormediated synaptic currents in dissociated cultured neurons (Nakahiro et al., 1989; Jones et al., 1992; Jones and Harrison, 1993) and in CA1 pyramidal neurons in vivo and in brain slices (Nicoll et al., 1975; Lukatch and MacIver, 1997; Banks and Pearce, 1999). $\mathrm{GABA}_{\mathrm{A}}$ receptors have modulatory binding sites for benzodiazepines, barbiturates, and anesthetics, all of which potentiate responses to GABA (for review, see Tanelian et al., 1993; MacDonald and Olsen, 1994). This prolongation of inhibitory currents would result in enhanced synaptic inhibition and contribute to the

\footnotetext{
Received Feb. 16, 2000; revised May 22, 2000; accepted May 24, 2000.

This work was supported by National Institutes of Health Grants GM54767 and GM56308 (M.B.M). K.N. was also supported by a postdoctoral research fellowship from Uehara Memorial Foundation, Tokyo, Japan. We thank Frances A. Monroe for technical assistance.

Correspondence should be addressed to Dr. Koh-ichi Nishikawa, Department of Anesthesiology, A-1050, Weill Medical College of Cornell University, 525 East 68th Street, New York, NY 10021. E-mail: nishikaw@med.gunma-u.ac.jp.

Copyright (c) 2000 Society for Neuroscience $0270-6474 / 00 / 205915-09 \$ 15.00 / 0$
}

IPSCs were increased by halothane (two- to threefold) in both types of neuron. On the other hand, halothane effects on resting membrane potentials were variable but minimal in both types of neurons. In current-clamp recordings, halothane depressed EPSP amplitudes and increased IPSP amplitudes recorded from both types of neurons. In addition, halothane increased the failure rate of synaptically evoked action potentials. Taken together, these data provide evidence that halothane increases $\mathrm{GABA}_{\mathrm{A}}$ receptor-mediated synaptic inhibition between synaptically connected interneurons and depresses excitatory transmission, similar to effects observed in pyramidal neurons.

Key words: GABA; miniature synaptic current; IPSC; EPSP; action potential; Schaffer-collateral; synaptic inhibition; glutamate; CA1; anesthesia anesthetic-induced depression of the CNS. However, few studies have investigated direct effects of general anesthetics on hippocampal inhibitory interneurons. Although halothane has been shown to depress EPSC amplitudes recorded from interneurons located in the CA1 stratum oriens/alveus area (Perouansky et al., 1996), detailed studies of general anesthetic effects on intrinsic membrane and synaptic properties of inhibitory hippocampal interneurons are lacking.

The aim of the present study was to compare the actions of a general anesthetic, halothane, on CA1 pyramidal cells and inhibitory GABAergic interneurons located at the border of stratum lacunosum-moleculare (SL-M) and stratum radiatum (SR) of rat hippocampal slices. In particular, we sought (1) to determine whether halothane affects properties of both spontaneous and evoked IPSCs in pyramidal cells and interneurons, (2) to examine whether halothane alters the membrane excitability of both types of neurons, and (3) to test whether halothane affects synaptically evoked action potentials (APs) recorded from both neuron types.

\section{MATERIALS AND METHODS}

Brain slice preparation. Experiments were performed on brain slices isolated from young male Sprague Dawley rats (55-88 gm). Protocols were approved by the Institutional Animal Care Committee at Stanford University and adhered to published guidelines of the National Institutes of Health, the Society for Neuroscience, and the American Physiological Society. Rats were anesthetized with diethyl ether and killed by decapitation, and brains were quickly removed and placed in cold $\left(1-2^{\circ} \mathrm{C}\right)$, oxygenated artificial CSF [ACSF; ionic composition (in mM): $\mathrm{Na}^{+} 151.25, \mathrm{~K}^{+}$ $3.5, \mathrm{Ca}^{2+} 2.0, \mathrm{Mg}^{2+} 2.0, \mathrm{Cl}^{-} 131.5, \mathrm{HCO}_{3}{ }^{-} 26.0, \mathrm{SO}_{4}{ }^{-} 2.0, \mathrm{H}_{2} \mathrm{PO}_{4}{ }^{-} 1.25$, and glucose 10.0]. Brains were sectioned in the coronal plane into $500-$ $\mu \mathrm{m}$-thick slices using a Vibratome (Vibratome Series 1000, Boston, MA). Slices were then hemisected and placed on filter papers (Millipore Corp., Bedford, MA) at the interface of a humidified carbogen $\left(95 \% \mathrm{O}_{2}-5 \%\right.$ $\mathrm{CO}_{2}$ ) gas phase and ACSF liquid phase. Slices were allowed at least $1 \mathrm{hr}$ for recovery at room temperature $\left(21-24^{\circ} \mathrm{C}\right)$ before submersion in ACSF in a recording chamber.

Electrophysiology. Whole-cell patch-clamp recordings were made from visualized pyramidal cells or interneurons in the CA1 area of rat hippocampal slices as described previously (Dodt and Zieglgansberger, 1990). Slices were constantly perfused with room temperature $\left(21-24^{\circ} \mathrm{C}\right) \mathrm{ACSF}$ at a rate of $2-2.5 \mathrm{ml} / \mathrm{min}$ in a recording chamber mounted on the stage of an upright Axioskop microscope (Zeiss, Jena, Germany). Near infrared 
light illuminated the brain slice through the glass bottom of the recording chamber and was collected by a water immersion objective $(40 \times)$ above the slice. The magnified image was collected by an intensified CCD camera (COHU Inc., San Diego, CA) with contrast enhancement. The image of interneurons was displayed on a video monitor, and glass patch pipettes were visually advanced using a micromanipulator (MP-285, Sutter Instruments, Novato CA) through the slice to the surface of the cell.

Patch pipettes were made from borosilicate glass (KG33; $1.5 \mathrm{~mm}$ outer diameter, $1.0 \mathrm{~mm}$ inner diameter; Garner Glass Company, Claremont, CA) using an electrode puller (PP-830, Narishige, Tokyo, Japan). The resistance of the pipette was 4-6 M $\Omega$ when filled with internal solutions. Two kinds of internal solutions were used: (1) a potassium chloride-based solution containing (in mM): $100 \mathrm{KCl}, 10 \mathrm{EGTA}, 40 \mathrm{HEPES}, 5 \mathrm{MgCl}_{2}, 2$ ATP, $1.5 \mathrm{GTP}, \mathrm{pH}$ adjusted to 7.25 with $\mathrm{KOH}$, and (2) a potassium gluconate-based solution containing (in $\mathrm{mM}$ ): $100 \mathrm{~K}$-gluconate, 10 EGTA, 40 HEPES, $5 \mathrm{MgCl}_{2}$, 2 ATP, $0.3 \mathrm{GTP}, \mathrm{pH}$ 7.25. $\mathrm{KCl}$ internal solutions were used to reverse the intracellular chloride ion concentrations to allow better resolution of spontaneous and miniature IPSCs in voltage-clamp recordings. K-gluconate solutions were used for current-clamp recordings, so the impermeable ion (gluconate) would not contribute to anestheticinduced changes in resting membrane potential (RMP) or current-voltage relations. In voltage-clamp recordings, $N$-(2,6-dimethylphenylcarbamoylmethyl)-triethylammonium bromide (QX-314, $1 \mathrm{~mm}$ ) was included in the pipette solution to prevent voltage-dependent $\mathrm{Na}^{+}$currents (Regehr and Tank, 1992). The osmolarity of the solutions was $300 \pm 5 \mathrm{mOsm}$. The series resistance was typically $10-50 \mathrm{M} \Omega$ immediately after the whole-cell recordings were obtained and was compensated by $>80 \%$. Membrane potentials and currents were monitored with an Axoclamp 2B amplifier (Axon Instruments, Foster City, CA), acquired through an A/D converter (Data Transition, $250 \mathrm{kHz}$ ) onto a Pentium-based computer. Data acquisition and analysis were performed using DataWave version 5.1 (DataWave Technologies, Longmont, CO) and IGOR Pro (WaveMetrics, Lake Oswego, OR). The current and voltage traces were filtered at $1 \mathrm{kHz}$ and digitized at $10 \mathrm{kHz}$.

Evoked synaptic currents and potentials were elicited using bipolar tungsten electrodes (Frederick Haer and Co., Bowdoinham, ME). These electrodes were placed at the SL-M-SR border to stimulate the Schaffercollateral commissural (SCC) pathway (for pyramidal cell stimulation; see Fig. $1 A$ ) or near the patched interneuron for stimulation of synaptic inputs. Monosynaptic $\mathrm{GABA}_{\mathrm{A}}$ receptor-mediated IPSCs were isolated by bath application of ( \pm )-2-amino-5-phosphonopentanoic acid (AP-5) (100 $\mu \mathrm{M})$ and 6-cyano-7-nitro-quinoxaline-2,3-dione (CNQX) $(17.2 \mu \mathrm{M})$ to block NMDA and AMPA receptor-mediated synaptic currents. The remaining currents were completely blocked by additional bath application of bicuculline $(10 \mu \mathrm{M})$ (data not shown). To characterize the kinetics of IPSCs, $10-90 \%$ rise time and the time to $63 \%$ of the decay $\left(\tau_{\text {decay }}\right)$ on exponential curve fitting were measured. The criteria for accepting a recording for analysis were that neurons had at least a $-50 \mathrm{mV}$ resting membrane potential, overshooting action potentials, and at least $200 \mathrm{M} \Omega$ input resistance for interneurons.

Application of volatile anesthetics and concentration measurement. The inhalation anesthetic halothane was applied using a carrier gas $(95 \%-\mathrm{O} 2 /$ $5 \%-\mathrm{CO}_{2}$ ) and calibrated commercial vaporizer (Fluotec 3, Fraser Harlake, Orchard Park, NY). During experiments, the gas-phase anesthetic concentration in the ACSF reservoir $(100 \mathrm{ml})$ was continuously monitored using a Datex 254 agent monitor (Datex, Helsinki, Finland). To determine the extent of loss of volatile anesthetic agent in the recording chamber, aqueous phase concentrations of anesthetics were previously determined using an electrochemical method (Hagan et al., 1998). Clinically relevant concentrations of the volatile anesthetic halothane $(0.35 \mathrm{mM} \cong 1.2 \mathrm{vol} \%)$ were used throughout this study. Solutions containing anesthetics were changed rapidly and accurately using a computerized perfusion system (ValveBank8, AutoMate Scientific, Oakland, CA). High quality polytetrafluorethylene was used for reservoirs, valves, and tubing to minimize volatile anesthetic loss and drug binding.

Animals/chemicals. All rats were obtained from Simonsen Laboratories (Gilroy, CA). Chemicals for the ACSF were reagent grade or better and obtained from J. T. Baker (Philadelphia, PA) or Sigma (St. Louis, MO).

Statistics. Data were expressed as mean $\pm \mathrm{SD}$, unless stated otherwise. Statistical significance of data from control and halothane groups was determined using the Student's $t$ test. One-way ANOVA was used to compare differences from three or more groups.

\section{RESULTS}

\section{Identification of pyramidal neurons and inhibitory interneurons located at the border of SL-M-SR}

With use of infrared differential inference contrast (DIC) microscopy, inhibitory interneurons located in the border of SL-M-SR were readily distinguished morphologically from pyramidal neurons and other cells such as astrocytes, by the characterization of relatively bright somata with large dendrites. Electrophysiological properties confirmed these morphological criteria of cell type; interneurons had a slightly more negative resting membrane potential $(-59.8 \pm 2.8 \mathrm{mV}, n=38)$ than pyramidal neurons $(-58.6 \pm$
A
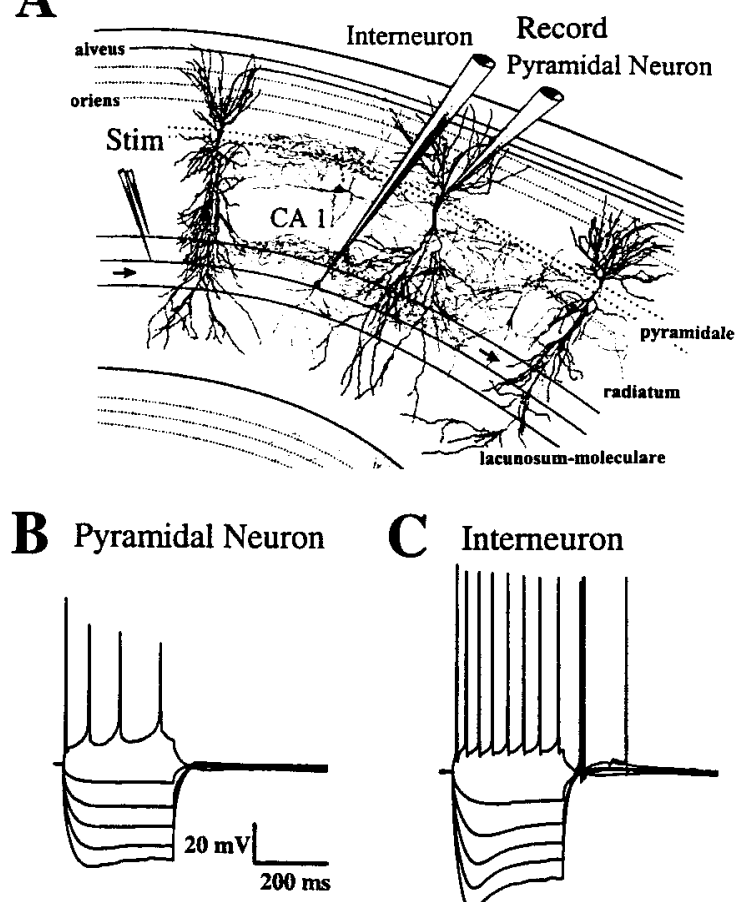

C Interneuron
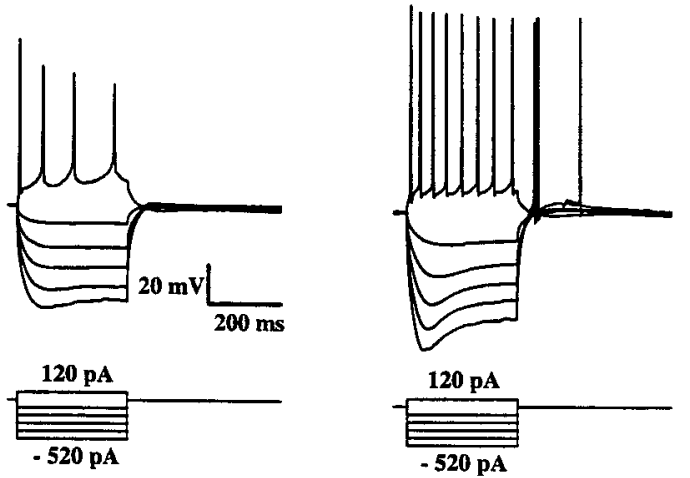

Figure 1. Identification of pyramidal neurons and interneurons near the border between SL-M and SR in rat hippocampal slices. $A$, Diagram of the area CA1 of a rat hippocampal slice showing the placement of bipolar stimulating tungsten electrodes (Stim) and recording patch electrodes (Record). The Stim was placed in the SL-M-SR border to evoke IPSCs and EPSPs in pyramidal cells and interneurons located at the SL-M-SR border. Under infrared DIC microscopy, pyramidal neurons with cell bodies located in the stratum pyramidale had apical dendrites passing through the stratum radiatum. Interneurons in the SL-M-SR border had large somata with dendrites that projected in many directions. Current-clamp recordings using a potassium gluconate internal solution show voltage responses to depolarizing $(300 \mathrm{msec},+120 \mathrm{pA})$ and hyperpolarizing (300 msec, from -120 to $-520 \mathrm{pA})$ current injections. Typical accommodating $(B)$ and nonaccommodating responses $(C)$ of pyramidal cells and interneurons, respectively, were observed after depolarizing current injection. Anodal break spikes were observed after hyperpolarizing current injection in many interneurons.

$3.6 \mathrm{mV}, n=18)$, but there was no statistical difference $(p=0.40)$. Figure $1 B$ illustrates the representative responses of pyramidal cells and interneurons to depolarizing and hyperpolarizing current injection into the soma. Interneurons could be distinguished electrophysiologically from pyramidal neurons by spike adaptation. Pyramidal neurons typically fired action potentials of longer duration and exhibited frequency adaptation (Fig. $1 B$, left), whereas interneurons were characterized by their fast action potentials and high-frequency discharge with little frequency adaptation or decrease in action potential amplitudes (Fig. $1 B$, right). Also, interneurons exhibited higher membrane input resistances $(270 \pm 23$ $\mathrm{M} \Omega$ ) than pyramidal neurons (range, 50-200 M $\Omega$ ). These findings are in accordance with the evoked firing patterns of CA1 interneurons recorded from hippocampal slices with intracellular microelectrodes (Lacaille et al., 1987; Lacaille and Schwartzkroin, 1988) and with whole-cell recording (Williams et al., 1994). In contrast, CA1 pyramidal neurons generate repetitive firing that accommodates during maintained depolarization (Madison and Nicoll, 1984).

\section{Halothane effects on stimulus-evoked IPSCs recorded from pyramidal cells and interneurons}

In hippocampal CA1 pyramidal neurons, two kinetically distinct forms of $\mathrm{GABA}_{\mathrm{A}}$ receptor-mediated synaptic inhibition have been 


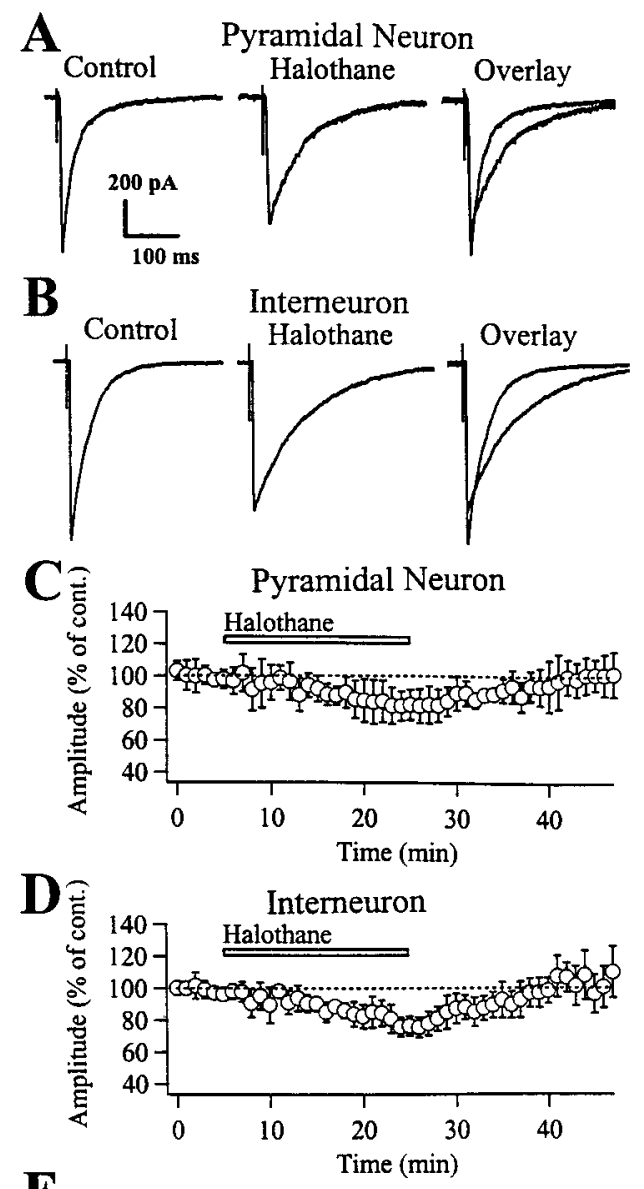

$\mathbf{E}$

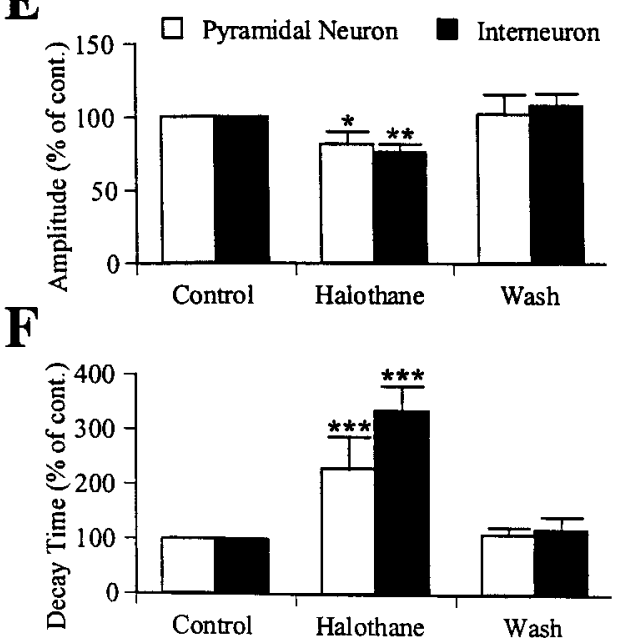

Figure 2. The effects of halothane on pharmacologically isolated GABA receptor-mediated IPSCs recorded from pyramidal cells and SL-M-SR interneurons. $A$, Representative traces of stimulus-evoked monosynaptic IPSCs recorded from pyramidal cells using whole-cell voltage-clamp recording $(-60 \mathrm{mV})$ in response to electrical stimulation of the SL-M-SR border were obtained in the presence of glutamate receptor antagonists APV $(100 \mu \mathrm{M})$ and CNQX $(17.2 \mu \mathrm{M})$. Under these conditions, only monosynaptic $\mathrm{GABA}_{\mathrm{A}}$ receptor-mediated IPSCs could be evoked, and bicuculline $(10 \mu \mathrm{M})$, a $\mathrm{GABA}_{\mathrm{A}}$ receptor antagonist, completely blocked these currents (data not shown). Halothane $(0.35 \mathrm{~mm}, 20 \mathrm{~min})$ depressed evoked IPSC amplitudes and also prolonged the decay phase. These halothane effects were reversible after washout of the anesthetic. $B$, Stimulus-evoked IPSCs recorded from an interneuron were depressed in a similar manner by halothane. The whole-cell voltage-clamp recordings in interneurons $(-60$ $\mathrm{mV}$ ) were obtained as described in $A$. Graphs of IPSC amplitudes versus experimental time show the time course of halothane-induced depression of $\mathrm{GABA}_{\mathrm{A}}$ IPSC amplitudes in pyramidal cells $(C$, mean $\pm \mathrm{SD}, n=5)$ and SL-M-SR interneurons $(D$, mean $\pm \mathrm{SD}, n=6)$. All amplitudes were expressed as a percentage of the average of control recordings taken during the 5 min preceding anesthetic application. $E$, The amplitude of evoked reported: $\mathrm{GABA}_{\text {Afast }}$ and $\mathrm{GABA}_{\text {Aslow }}$ (Pearce, 1993). It has also been shown that halothane $(1.2 \mathrm{vol} \%)$ prolonged the decay of these two types of IPSCs similarly ( $\sim 2.5$-fold $)$, with minimal changes in IPSC amplitudes and rise times (Lukatch and MacIver, 1997). SL-M-SR border stimuli-evoked IPSCs recorded from pyramidal cells (Fig. 2A, Control) using bipolar tungsten electrodes were kinetic mixtures of $\mathrm{GABA}_{\text {Afast }}$ and $\mathrm{GABA}_{\text {Aslow }}$, but IPSCs could be evoked stably. The rise time was $2.3 \pm 0.8 \mathrm{msec}$, and $\tau_{\text {decay }}$ was $35.1 \pm 5.5 \mathrm{msec}(n=6)$. On the other hand, monosynaptic evoked IPSCs recorded from SL-M-SR interneurons showed faster kinetics in control: $1.3 \pm 0.4 \mathrm{msec}$ in the rise time and $32.8 \pm 7.9 \mathrm{msec}$ in $\tau_{\text {decay }}(n=5)$ (Fig. $2 B$, control). However, in our recording conditions, there was no statistical significance between evoked IPSC kinetics recorded from both types of neurons.

Bath-applied halothane ( $0.35 \mathrm{~mm} \cong 1.2 \mathrm{vol} \%, 20 \mathrm{~min})$ slightly but significantly inhibited the amplitude of evoked IPSCs of both pyramidal cells $(81.3 \pm 9.1 \%$ of control, $n=6, p<0.05)$ (Fig. $2 C)$ and SL-M-SR interneurons $(75.8 \pm 5.9 \%$ of control, $n=5, p<$ 0.01) (Fig. 2D). The time course of halothane effects on evoked IPSC amplitudes was slow; 15-20 min was needed to reach steadystate depression in both types of neurons. This inhibition was completely reversed after washout of halothane $(>30 \mathrm{~min})$. These effects were independent of postsynaptic holding potential and of placement of stimulating electrodes. The effects of a higher concentration of halothane $(2.2 \mathrm{vol} \%)$ were also tested. Halothane $(2.2$ vol\%, $20 \mathrm{~min}$ ) depressed the amplitude of evoked IPSCs to $59 \%$ of control in pyramidal cells $(n=4)$ and to $55 \%$ of control in interneurons $(n=5)$. This concentration was close to the $\mathrm{IC}_{50}$ for IPSC amplitude depression. In addition, halothane $(0.35 \mathrm{~mm} \cong 1.2$ vol\%, $20 \mathrm{~min})$ considerably prolonged the decay $\left(\tau_{\text {decay }}\right)$ of evoked IPSCs to $80.7 \pm 20.1 \mathrm{msec}(230.0 \pm 59.0 \%$ of control, $n=6, p<$ $0.001)$ in pyramidal cells and to $110.2 \pm 15.1 \mathrm{msec}(336.0 \pm 46.0 \%$ of control, $n=5, p<0.001$ ) in interneurons. A summary of normalized data from both types of neurons, showing effects of

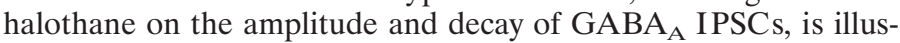
trated in Figure 2, $E$ and $F$. As a result of this prolongation, despite a small reduction in the peak amplitudes of evoked IPSCs, the total negative charge transfer increased to $175 \pm 30 \%$ of control $(n=6$, $p<0.01)$ in pyramidal neurons and to $213 \pm 25 \%$ of control $(n=$ $5, p<0.001)$ in interneurons.

\section{Halothane increases the frequency of action potential- independent IPSCs in both pyramidal cells and interneurons}

AP-independent $\mathrm{GABA}_{\mathrm{A}}$ receptor-mediated IPSCs [miniature IPSCs (mIPSCs)] were recorded from both pyramidal cells and SL-M-SR interneurons in the presence of tetrodotoxin (TTX, 1 $\mu \mathrm{M})$ used to block sodium channels that give rise to action potentials (Fig. $3 A$, top, $C$, top). The frequencies of mIPSCs varied from cell to cell and ranged between 0.5 and $3 \mathrm{~Hz}$ in control conditions. These mIPSCs had a faster rise time $(<1 \mathrm{msec})$ and a faster decay time constant $(<25 \mathrm{msec})$ compared with those of evoked IPSCs (see above). Kinetics of mIPSCs were similar to those of GABA $_{\text {Afast }}$ (Pearce, 1993; Lukatch and MacIver, 1997). The amplitude and time course of mIPSC remained stable for at least 60 min in control recordings.

Although halothane slightly depressed the amplitudes of mIPSCs, the most striking effects on mIPSCs were an increased frequency of events and prolongation of their decay phase (Fig. $3 A$, bottom, $B$,

IPSCs recorded from pyramidal cells and interneurons is expressed as a percentage of control. Halothane $(0.35 \mathrm{mM}, 20 \mathrm{~min})$ significantly depressed IPSC amplitudes in both pyramidal cells and interneurons. These effects were completely reversed $30 \mathrm{~min}$ after halothane wash $\left({ }^{*} p<0.05,{ }^{* *} p<\right.$ 0.01 vs control). Halothane also markedly prolonged the decay time constants of IPSCs in both pyramidal cells and interneurons $(F)$. The decay phase was fitted by a single exponential curve, and the time from peak amplitude to $63 \%$ of peak amplitude $\left(\tau_{\text {decay }}\right)$ was measured in averaged traces from at least 20 recordings. Bars represent SEM. $n=6$ for pyramidal cells and $n=5$ for interneurons $(* * *<<0.001$, ANOVA). 


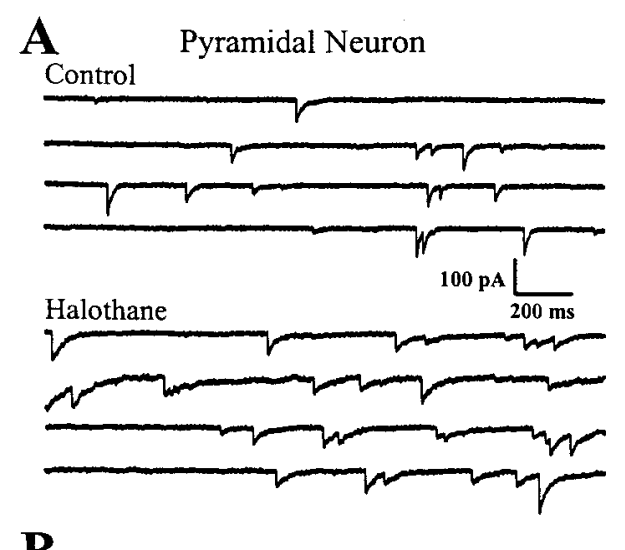

B
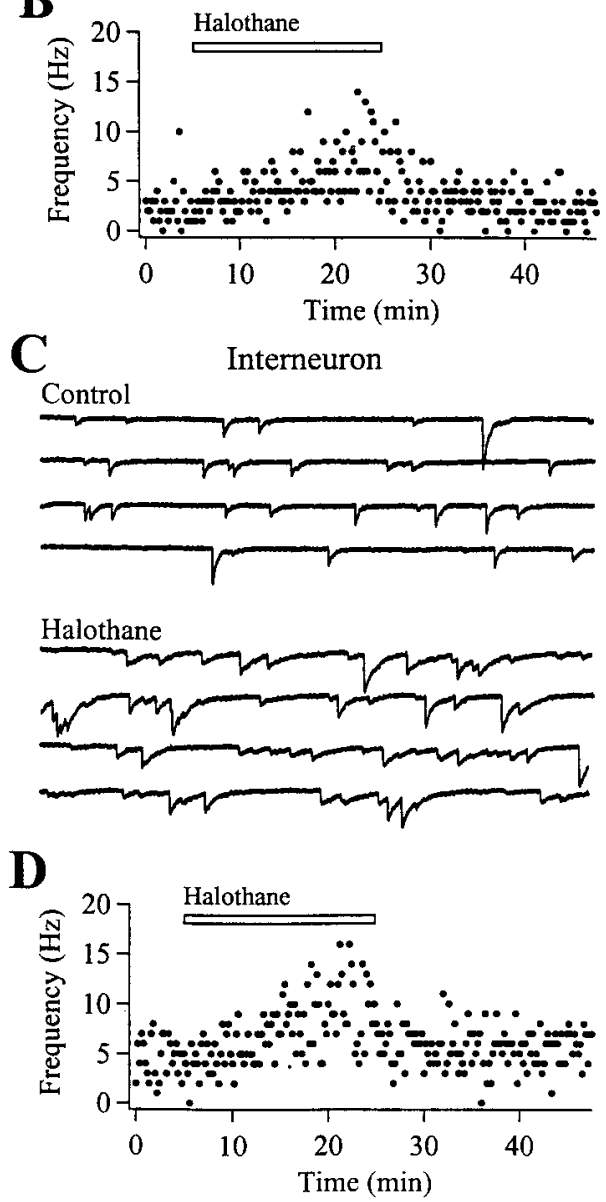

Figure 3. Halothane increases the frequency of miniature IPSCs and prolongs their decay phases recorded from both pyramidal cells and interneurons in the presence of CNQX $(17.2 \mu \mathrm{M})$, AP-5 $(100 \mu \mathrm{M})$, and TTX (1 $\mu \mathrm{M})$. For these recordings, patch pipettes were filled with KCl-based internal solution. These mIPSCs were completely blocked after application of bicuculline $(10 \mu \mathrm{M})$ (data not shown). A, Continuous recordings ( $8 \mathrm{sec}$ long) of mIPSCs recorded from a pyramidal neuron (2 sec/record); in control (top) and after halothane $(0.35 \mathrm{mM}, 20 \mathrm{~min}$, bottom $) . B$, Rate meter showing the halothane-induced increase in mIPSC frequency plotted against experimental time. The frequency increased from $0.5-2.5 \mathrm{~Hz}$ in control to $>6 \mathrm{~Hz}$ in the presence of halothane. $C$, Continuous recordings ( $8 \mathrm{sec}$ long) of mIPSCs recorded from an SL-M-SR border interneuron ( $2 \mathrm{sec} / \mathrm{record})$, in control (top) and after halothane $(0.35 \mathrm{mM}, 20 \mathrm{~min}$, bottom $)$. D, The frequency of mIPSCs increased from $\sim 3 \mathrm{~Hz}$ in control to over $7 \mathrm{~Hz}$ in the presence of halothane.

bottom). Halothane produced a two- to threefold increase in the frequency of mIPSCs in both pyramidal cells and interneurons (Fig. $3 C, D)$, indicating that halothane acts directly on presynaptic nerve terminals, independent of AP discharge activity of interneurons. Similar to observations for evoked IPSCs, the total negative charge
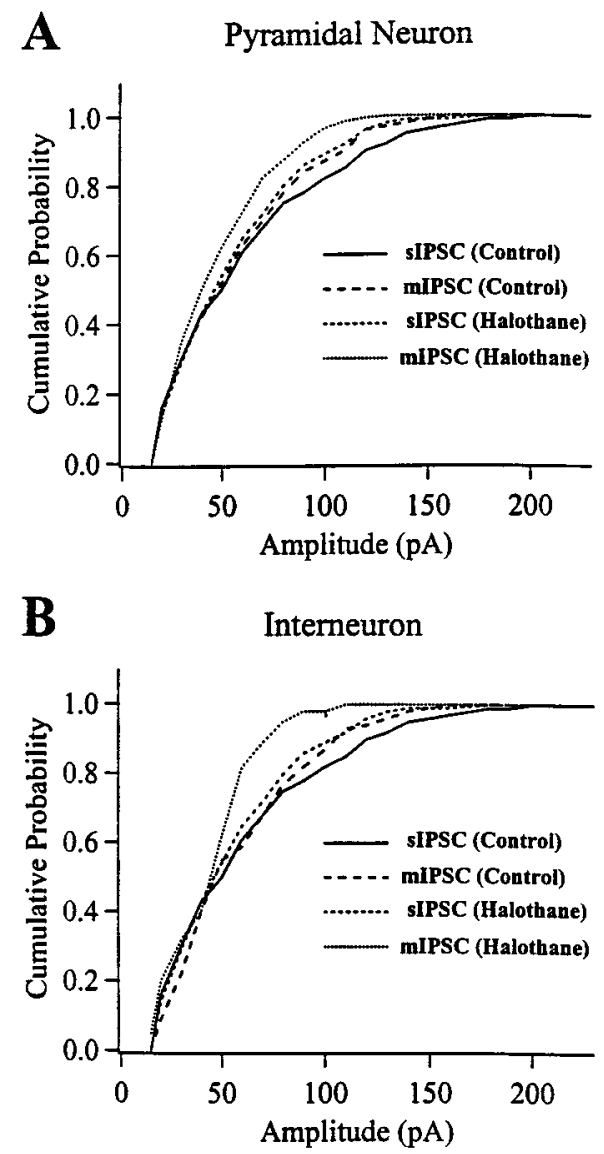

Figure 4. Halothane effects on cumulative probability of sIPSC and mIPSC amplitudes recorded from pyramidal cells $(A)$ and interneurons $(B$, at $-60 \mathrm{mV}$ ). AP-independent synaptic currents (mIPSCs) were recorded in the presence of TTX $(1 \mu \mathrm{M})$. Both AP-dependent and AP-independent components were included in sIPSC recordings. Halothane $(0.35 \mathrm{~mm}, 20$ min) considerably depressed both sIPSC and mIPSC amplitudes in both types of neurons. Synaptic currents with amplitudes $<15 \mathrm{pA}$ and with slow rise times were excluded in this study.

transfer of mIPSCs was greatly increased by halothane to $>300 \%$ in both types of neurons. This appeared to result from a nearly $100 \%$ increase in $\mathrm{mIPSC}$ frequency combined with a $200-300 \%$ increase in the decay time constant of IPSCs.

Spontaneous IPSCs (sIPSCs) consist of AP-independent synaptic currents and AP-dependent events. The latter is sensitive to TTX. To determine whether AP-dependent events were affected by halothane, we next examined the effects of halothane on these currents in pyramidal cells and interneurons in the absence of TTX. The majority of sIPSCs recorded in our recording condition were thought to be AP-independent IPSCs (mIPSCs), because the frequency (0.5$3 \mathrm{~Hz}$ ) and amplitude distributions of sIPSCs were almost identical to those of mIPSCs recorded in the presence of $1 \mu \mathrm{M}$ TTX (Fig. $4 A, B$ ). Thus AP-dependent events were relatively infrequent under control conditions in both types of neurons. It was not clear whether the frequency of AP-dependent events was increased by the anesthetic, because increased frequencies of larger amplitude IPSCs (presumed AP dependent $)$ were only rarely seen $(<10 \%)$. Halothane $(0.35 \mathrm{~mm}$, $20 \mathrm{~min}$ ) produced a small depression of sIPSC amplitudes (Fig. $4 A, B)$ together with a marked prolongation of the decay phase and smaller increase in frequency of sIPSCs in the majority of neurons studied. These data indicate that halothane has effects on SIPSCs similar to those observed for mIPSCs, suggesting that halothane only rarely increases the AP-dependent events.

Halothane effects on membrane properties of pyramidal cells and interneurons

Intrinsic membrane properties of pyramidal neurons and SL$\mathrm{M}-\mathrm{SR}$ interneurons were studied in current-clamp mode using 
A
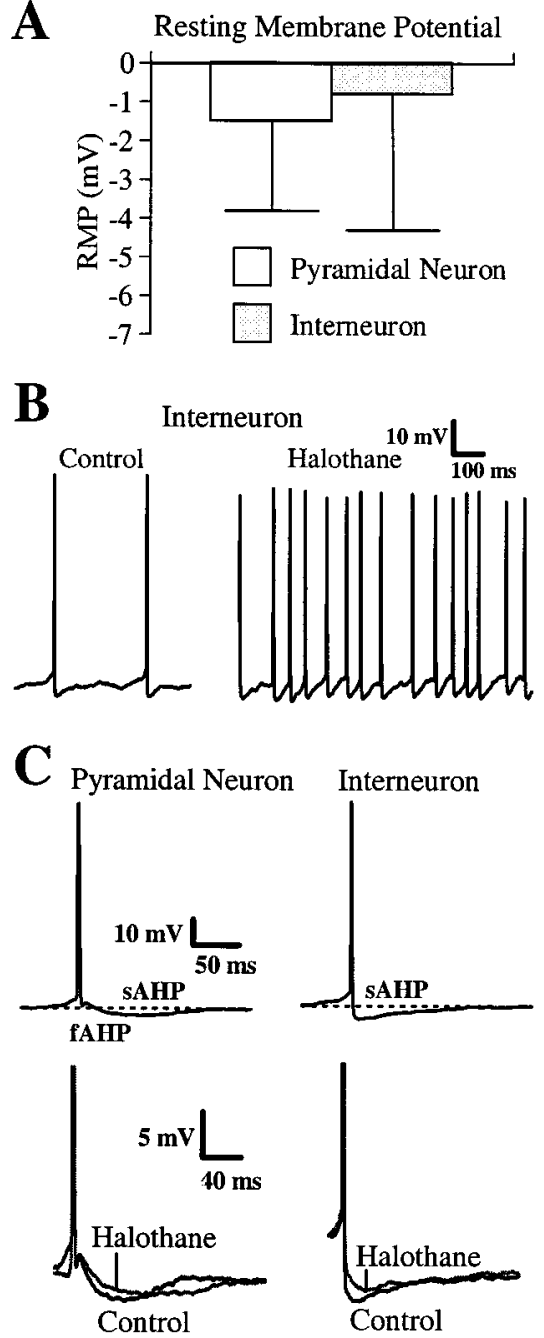

Figure 5. Halothane effects on intrinsic membrane properties of pyramidal cells and interneurons were studied with patch pipettes filled with $\mathrm{K}$-gluconate in the whole-cell current-clamp configuration. $A$, RMPs were slightly hyperpolarized by halothane $(0.35 \mathrm{~mm}, 20 \mathrm{~min})$ in both types of neuron, but these effects did not reach statistical significance because of its large variability. $B$, In some interneurons $(3 / 38)$, however, halothane considerably depolarized the cell $(>5 \mathrm{mV})$ and caused higher-frequency spontaneous discharge activity. These effects were completely reversed after washout of halothane. $C$, Spontaneous action potentials that were followed by an AHP were recorded in both neuron types. Halothane had little effect on AHPs.

patch pipettes filled with potassium gluconate. The majorities of SL-M-SR interneurons $(>90 \%)$ were typically silent at RMPs $(-59.8 \pm 2.8 \mathrm{mV})$ and showed irregularly occurring firing patterns. Addition of halothane $(0.35 \mathrm{~mm}, 20 \mathrm{~min})$ to the bath solutions produced a small hyperpolarization of $-1.5 \pm 2.3 \mathrm{mV}$ in pyramidal neurons $(n=18)$ and $-0.8 \pm 3.5 \mathrm{mV}$ in interneurons $(n=38)$ (Fig. $5 A)$. However, these effects did not reach statistical significance because the RMP change produced by halothane exhibited a considerable variation. In a majority of interneurons (28/38 cells, $74 \%)$, halothane-induced RMP changes were small $(<2 \mathrm{mV})$ and accompanied by a decrease of spontaneous firing rate. In rare cases (3/38 cells, $8 \%)$, halothane reversibly produced a considerable depolarization $(>5 \mathrm{mV})$ of the cell. As a result, halothane caused an increased discharge frequency of spontaneous action potentials in these cells (Fig. 5B).

APs in vertebrate neurons are followed by an afterhyperpolarization (AHP) that regulates the firing pattern and discharge frequency of neurons (Fig. 5C, top). Some studies have suggested that intravenous anesthetics may enhance a calcium-activated potassium current $\left(I_{\mathrm{AHP}}\right)$ that underlies this hyperpolarization
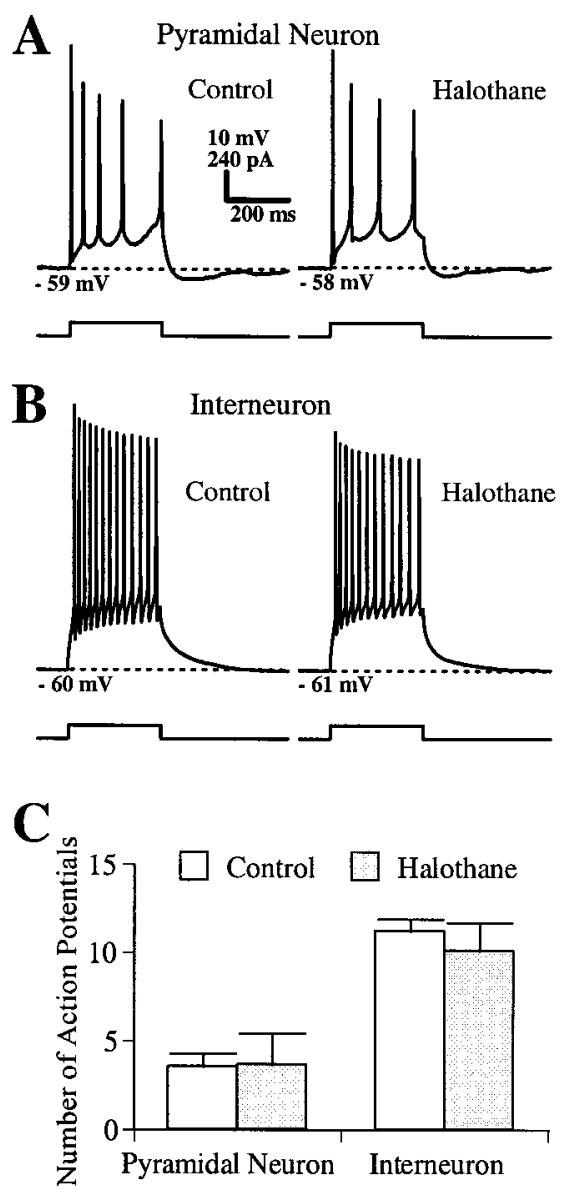

Figure 6. Halothane effects on voltage responses to depolarizing current injection $(120 \mathrm{pA}, 300 \mathrm{msec})$ to the cell. Recordings were made in wholecell current clamp using K-gluconate as the internal solution. $A$, Representative examples of halothane $(0.35 \mathrm{~mm})$ effects on AP discharge activity. Typically, accommodating responses were observed for pyramidal neurons $(A)$, and nonaccommodating responses were observed for interneurons (B). $C$, Action potential discharge induced by current injection $(120 \mathrm{pA}$, $300 \mathrm{msec}$ ) was not changed by halothane in either pyramidal cells or interneurons.

(Carlen et al., 1985); however, other laboratories have reported that volatile anesthetics inhibited the slow AHP (sAHP) in rat hippocampal neurons (Wann and Southan, 1992; Pearce, 1996). In the present study, halothane $(0.35 \mathrm{~mm}, 20 \mathrm{~min})$ produced little or no effect on either the fast AHP (fAHP) or the SAHP in pyramidal cells and interneurons (Fig. 5C, bottom).

In response to depolarizing current injections, CA1 pyramidal cells produced an accommodating train of action potentials (Fig. $6 \mathrm{~A}$, left), and interneurons showed a nonaccommodating response (Fig. 6B, left). Halothane had little effect on action potential discharge activity of both types of neuron (Fig. $6 A$, right, $B$, right). Halothane effects on the number of AP discharges induced by depolarizing current injection (120 pA) during the pulse (300 $\mathrm{msec}$ ) are shown in Figure $6 C$. Similar results were observed using larger current injections (500 pA) (data not shown). Representative examples for the effects of halothane on voltage traces in response to hyperpolarizing current injections are presented in Figure 7. Hyperpolarizing currents activated hyperpolarizationactivated cationic currents $\left(I_{\mathrm{h}}\right)$, causing a sag in the early portion of voltage traces, especially in interneurons (Fig. 7, compare $A, B$ ). In many interneurons ( $8 / 13$ cells), activation of $I_{\mathrm{h}}$ was enhanced by halothane (Fig. $7 B$, right) but not in other neurons (5/13 cells). In the former neuron type, the current-voltage relationship also indicated that the anesthetic increased the input resistance of interneurons (Fig. $7 B$ bottom); however, this change did not reach 

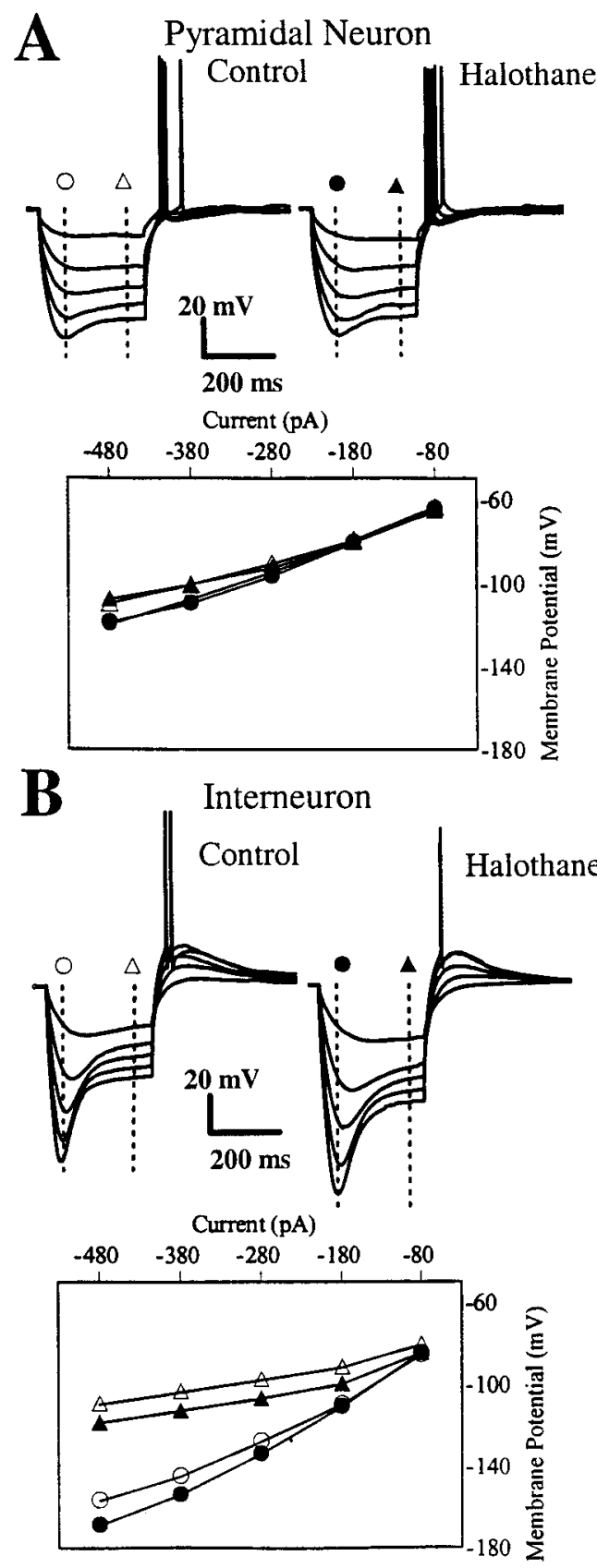

Figure 7. Sample traces (top) showing effects of halothane on voltage traces in response to hyperpolarizing current injections (from -80 to -480 $\mathrm{pA}, 300 \mathrm{msec}$ ) for pyramidal cells $(A)$ and interneurons $(B)$ were recorded in current-clamp mode using K-gluconate internal solution. The corresponding current-voltage relations were constructed for the early peaks $(O)$ and steady state $(\triangle)$ of responses to current injection indicated in top sample traces (bottom). Halothane effects are shown using the filled symbols. The $I-V$ relation was almost linear in pyramidal cells. Halothane increased the input resistance of interneurons in many neurons ( $8 / 13$ cells); typical traces are shown here. However, there was no difference in total cells (voltages at $-480 \mathrm{pA}$ were compared; $n=13, p=0.15$ ).

statistical significance because of its variability. This effect was not observed for pyramidal cells (Fig. 7A).

\section{Effects of halothane on synaptically evoked action potentials}

To determine how halothane affects the synaptically evoked discharge of pyramidal cells and interneurons, stimulus-evoked action potentials were recorded in whole-cell current-clamp mode. Tungsten electrodes were placed at the SL-M-SR border for the stimulation of pyramidal cells. Minimal afferent fiber input stimulation
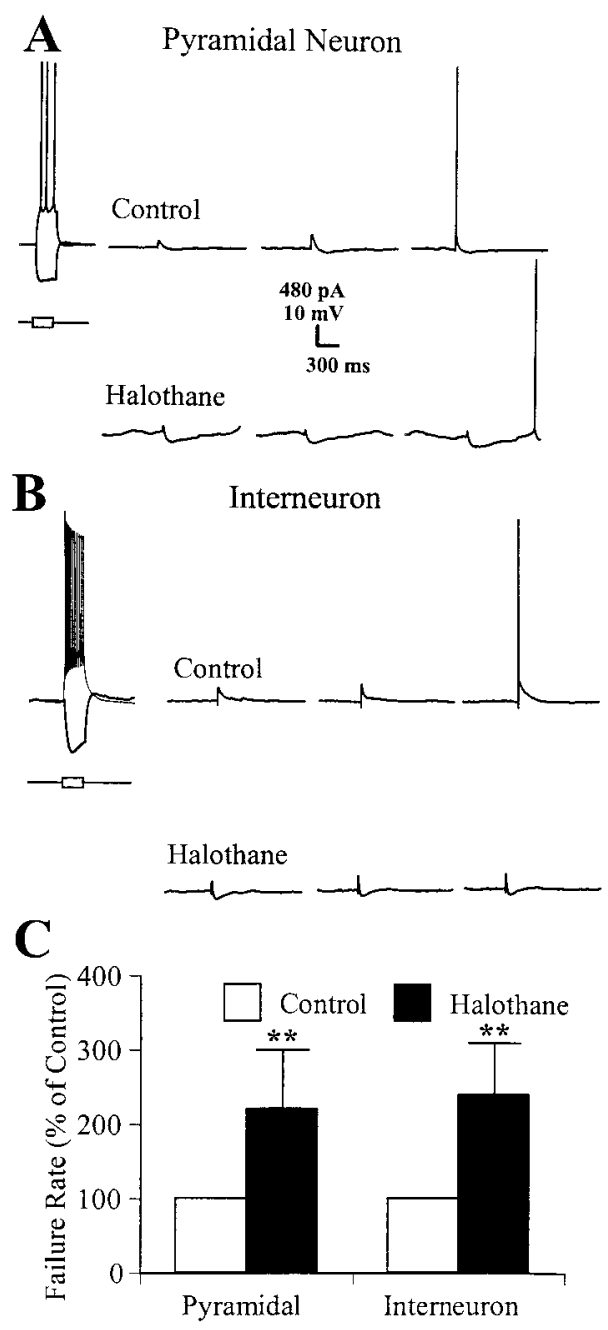

Figure 8. Effects of halothane on synaptically evoked APs recorded in the current-clamp configuration using K-gluconate internal solution. $A$, Physiological characterization of a pyramidal cell; voltage responses to depolarizing and hyperpolarizing currents $(300 \mathrm{msec}, \pm 120 \mathrm{pA})$ were shown. Minimal afferent fiber input stimulation evoked only a small amplitude EPSP in normal ACSF solution (left). Voltage responses evoked by higherintensity stimulation ranged from a larger amplitude EPSP (middle) to solitary AP (right). Stimulus intensity was adjusted to evoke $\sim 50 \%$ discharge after synaptic activation in control recordings. The amplitude and duration of evoked solitary APs were similar to those of spontaneous APs. $B$, Physiological characterization of an interneuron $(300 \mathrm{msec}, \pm 120 \mathrm{pA})$, showing an EPSP with small amplitude (left), with larger amplitude (middle), and solitary APs (right). Middle and right traces were evoked by the same intensity stimulus to obtain an $\sim 50 \%$ failure rate for action potentials in control condition. The failure of evoked solitary APs was frequently observed in the presence of halothane. $C$, Halothane $(0.35 \mathrm{~mm}, 20 \mathrm{~min})$ significantly increased the failure rate of synaptically evoked APs in both types of neuron ( $n=6$ each, $* * p<0.01$ vs control).

EPSPs, followed by IPSPs in pyramidal cells (Fig. 8A, Control, left). Responses evoked by higher-intensity stimulations ranged from an EPSP without an AP (Fig. $8 A$, Control, middle) to an EPSP with a solitary AP and hyperpolarization (Fig. $8 A$, Control, right). The amplitudes and duration of evoked solitary APs were similar to those of spontaneous APs (Fig. $5 C$ ). To test the effect of halothane on solitary AP failure rate, stimulation intensity was adjusted to evoke APs with an $\sim 40-50 \%$ proportion of failures. The failure rate was increased by halothane (Fig. $8 A$, Halothane). Similarly, synaptically evoked EPSPs and solitary APs were also recorded from interneurons (Fig. $8 B$ ). Halothane effects on the failure rate were summarized (Fig. $8 C$ ). Halothane $(0.35 \mathrm{~mm}, 20 \mathrm{~min})$ significantly increased the failure rate of evoked solitary APs in both types of neurons ( $n=6$ for, each). A more detailed study of synaptically evoked postsynaptic potentials is shown in Figure 9. 
A
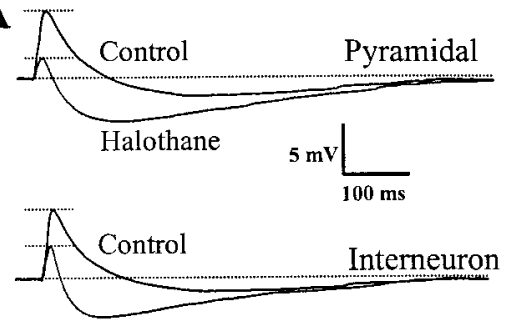

Halothane

B

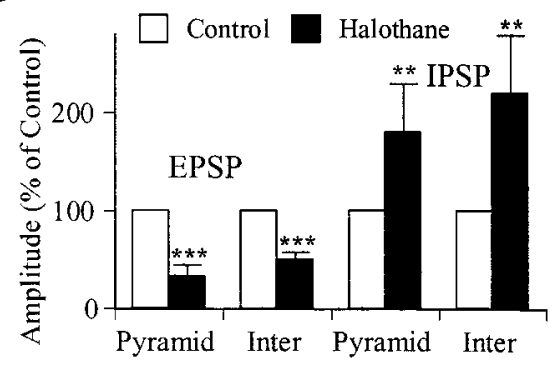

Figure 9. Effects of halothane on postsynaptic potentials of pyramidal cells and interneurons. EPSPs followed by IPSPs were elicited by single-pulse stimulation to SCC fibers and recorded in current-clamp mode using K-gluconate internal solution. $A$, Although the peak latency of the EPSP was unchanged, halothane depressed synaptically evoked EPSP amplitudes and increased IPSP amplitudes in both a pyramidal neuron (top) and an interneuron (bottom). B, Halothane effects on both EPSP and IPSP amplitudes are summarized $\left(n=6\right.$ in each type of neuron; ${ }^{* *} p<0.01,{ }^{* * *} p<$ $0.001)$.

Although the peak latency of EPSPs was unchanged, halothane application depressed EPSP amplitudes and increased IPSP amplitudes in both neuron types at normal RMPs (Fig. 9A). It is unlikely that anesthetic-induced membrane hyperpolarization contributed to the depression of EPSP amplitudes, because hyperpolarizations were small and would be expected to increase apparent EPSP amplitudes by moving away from the reversal potential for these glutamate-mediated sodium-calcium currents. As shown in Figure $9 B$, halothane significantly depressed EPSP amplitudes (33.0 \pm $12.0 \%$ of control in pyramidal cells, $n=6, p<0.001 ; 50.1 \pm 8.0 \%$ of control in interneurons, $n=6, p<0.001$ ) and facilitated IPSP amplitudes (180.0 $\pm 49.8 \%$ of control in pyramidal cells, $n=6, p<$ $0.01 ; 220.5 \pm 60.3 \%$ of control in interneurons, $n=6, p<0.01)$.

\section{DISCUSSION}

Our results confirm previous observations that anesthetics depress CA1 pyramidal neuron excitability by enhancing $\mathrm{GABA}_{\mathrm{A}}$ receptormediated inhibition and by depressing glutamate receptormediated excitation. These synaptic actions appear to play the major role in anesthetic-induced depression of the CA1 circuit, outweighing effects on postsynaptic excitability. We have extended these observations to include an anesthetic-induced depression of inhibitory interneurons, with a concomitant increase in $\mathrm{GABA}_{\mathrm{A}}$ receptor-mediated inhibition between these synaptically connected cells. These results have important implications for both the mechanisms of anesthetic action and the consequences of studying synaptic circuit function in halothane-anesthetized animals.

\section{Identification of interneurons located at the SL-M-SR border}

We used infrared DIC microscopy to facilitate whole-cell patchclamp recordings from SL-M-SR interneurons. In contrast to pyramidal cells, interneurons are rather diverse morphologically and electrophysiologically (Freund and Buzsaki, 1996). To minimize this diversity of interneurons, we selected neurons that had relatively small cell bodies located at the SL-M-SR border, because these neurons are reported to receive less spontaneous syn- aptic input and to fire at slower rates (Lacaille and Schwartzkroin, 1988). However, even in the same stratum, electrophysiological diversity of interneurons has also been reported (Parra et al., 1998). In our recording conditions, the majority $(>90 \%)$ of SL-M-SR interneurons tested showed relatively low spontaneous discharge activity $(0.3 \mathrm{~Hz}$ or less) and irregularly occurring firing patterns. These data are in accordance with previous findings that SL-M interneurons fire irregularly, whereas stratum oriens interneurons show regular discharge patterns (Parra et al, 1998). In some cases, high-frequency burst firing was observed; these cells were excluded from analysis of membrane potential changes. Taken together, the SL-M-SR interneurons analyzed here showed some homogeneity at least in terms of physiological properties.

\section{Halothane enhances GABA receptor-mediated synaptic inhibition}

Enhanced $\mathrm{GABA}_{\mathrm{A}}$ receptor-mediated synaptic inhibition was one of the earliest observed effects produced by anesthetics seen in vivo and in brain slice preparations (Nicoll, 1972; Nicoll et al., 1975; Pearce et al., 1989; Mody et al., 1991; Antkowiak and Heck, 1997). This enhanced synaptic inhibition appears to come about via actions at both presynaptic and postsynaptic sites. At presynaptic sites, anesthetics increase the release of GABA, evident as an increased mIPSC frequency in pyramidal cells and interneurons (Fig. 3)(Murugaiah and Hemmings, 1998; Banks and Pearce, 1999). This presynaptic effect involved actions directly on nerve terminals, because the increased mIPSC frequency persisted in the presence of TTX. An additional presynaptic action that increases the AP discharge activity of a minor population of interneurons (Fig. $5 B$ ) could also contribute to an increased GABA release. This is an important aspect of halothane actions, because the postsynaptic effects on GABA-gated chloride channels are dependent on the presence of GABA in the synaptic cleft to provide receptor occupancy (Jones and Harrison, 1993; Harris et al., 1994; MacDonald and Olsen, 1994; Li and Pearce, 2000).

The anesthetic effect seen at GABA-mediated synapses involves postsynaptic sites associated with $\mathrm{GABA}_{\mathrm{A}}$ receptors (Tanelian et al., 1993; MacDonald and Olsen, 1994). This was observed as a prolongation of IPSC decay (Figs. 2, 3). This prolongation results in approximately threefold increase of inhibitory conductance, despite a small decrease in IPSC amplitudes produced by halothane (Jones et al., 1992; Banks and Pearce, 1999). In currentclamp recordings, halothane produced both an increase in the apparent amplitude and a prolongation of IPSP decay, which contributed to the anesthetic-induced depression of synaptically driven spike discharge (Figs. 8,9). These effects are known to involve a direct action on GABA receptor-ion channels, because they have been observed on isolated receptors in expression systems and because effects can be abolished by mutations made in GABA receptors (Mihic et al., 1997; Koltchine et al., 1999; Pistis et al., 1999). It should be noted, however, that halothane also depressed the synaptically evoked discharge of interneurons (Fig. 8) by depressing glutamate receptor-mediated EPSPs in these cells (Fig. $9 A$ ). This would tend to diminish the role of enhanced GABA receptor-mediated inhibition for the overall depression of population spike (PS) responses produced by halothane (MacIver and Roth, 1988; Wann and Southan, 1992).

\section{Halothane depressed glutamate-mediated excitatory synaptic transmission}

Our results confirm previous reports that halothane produces a marked depression of glutamate-mediated synaptic responses recorded from both pyramidal cells (MacIver et al., 1989) and hippocampal interneurons (Perouansky et al., 1996). This anestheticinduced depression of glutamate receptor-mediated responses appears to involve presynaptic and postsynaptic sites of action, analogous but opposite to effects seen for $\mathrm{GABA}_{\mathrm{A}}$ receptormediated responses. Thus, anesthetics depress the release of glutamate from nerve terminals, evident in biochemical measures of glutamate release from synaptosomes and as an increase in paired- 
pulse facilitation that accompanies the anesthetic-induced depression of EPSPs (Schlame and Hemmings, 1995; MacIver et al., 1996; Nishikawa and Kidokoro, 1999; Nishikawa and MacIver, 2000). Some of this presynaptic depression results from a reduction in nerve terminal depolarization, secondary to depression of AP conduction in presynaptic axons (Harris and Bruno, 1985), and this can account for up to $30 \%$ of the halothane-induced depression of EPSP amplitudes recorded from hippocampal pyramidal neurons (Mikulec at al., 1998). The remaining depressant effects are thought to involve sites associated with calcium entry into nerve terminals or vesicular release processes (Daniell and Harris, 1988). Depression of postsynaptic membrane depolarization to released glutamate appears to play a role for some anesthetics but not for halothane (Richards and White, 1975; Nishikawa and MacIver, 2000).

\section{Halothane did not depress postsynaptic excitability}

Only minimal depressant effects produced by halothane were evident for the postsynaptic membrane excitability of either pyramidal cells or interneurons. AP discharge in response to depolarizing current injection was not altered (Fig. 6), nor were the threshold, rise time, and amplitude of spikes altered (Fig. 5). Spike train frequency and AHPs were only slightly depressed by halothane (Figs. 5, 6), and anesthetic-induced hyperpolarization of membrane potential was small and variable in both types of neuron. These findings add to the controversy regarding possible postsynaptic actions of halothane; evidence indicates that membrane hyperpolarization can contribute to halothane-induced depression (Nicoll and Madison, 1982; MacIver and Kendig, 1991) and appears to result from increased potassium conductances (Sirois et al., 1998; Patel et al., 1999). Other studies indicate that potassium currents are relatively insensitive to anesthetics (Franks and Lieb, 1994; Magyar and Szabo, 1996). The discordance in the literature most likely comes about from the relatively small effects seen at normal RMPs and from methodological differences. For example, in the present study, most G-protein-linked ion channels (including many types of potassium channels) would be disrupted by intracellular dialysis from the internal solution of patch pipettes, so some effects on baseline potassium currents or the AHP would have been missed. However, these postsynaptic actions could not have contributed much to the overall depression of synaptically evoked responses. Previous studies have shown that the synaptically mediated PS was depressed by halothane (MacIver, 1997), whereas antidromic PS remained unaltered (MacIver and Roth, 1988). Thus, halothane actions at chemical synapses appear to contribute much more to the depression of CA1 neuron responses, compared with postsynaptic actions.

\section{Halothane depressed inhibitory interneurons}

Synaptically evoked discharge of inhibitory interneurons was strongly depressed by halothane, to the same extent as was evident for pyramidal neurons (Fig. 8). Similarly, synaptic inhibition between interneurons was increased to a degree comparable to that in pyramidal neurons (Figs. 2, 9). The combined effect would result in a depression of activity in local interneuron networks of the CA1 area. This would counteract depressant effects on pyramidal neurons, by decreasing polysynaptic tonic and feedforward and feedback synaptic inhibition. Although not evident in monosynaptic IPSCs recorded in the present study, these polysynaptic effects on interneurons would be expected to alter information flow through the CA1 circuit. Together with the marked prolongation of IPSC decay (Fig. 2), this would certainly contribute to an alteration of synchronized discharge activity of pyramidal cells. Synchronized activity of CA1 neurons appears to play important roles in learning and memory (Huerta and Lisman, 1995; Thomas et al., 1998; Yeckel and Berger, 1998) and sleep cycles (Skaggs and McNaughton, 1998) both in hippocampus and in other cortical areas (Kocsis et al., 1999). Thus, studies that use halothane in anesthetized animals must take into account not only the depressant effects on synaptic transmission but also the more complex actions that would result from a combination of interneuron circuit depression and prolonged inhibition.

Although halothane produced essentially the same effects on inhibitory interneurons and pyramidal cells, these results do not rule out the possibility that similar effects will occur in other neuron types. For example, some cells that express different combinations of potassium channels could be more sensitive to the postsynaptic actions of halothane in other brain regions. What is clear though is that halothane acts at several presynaptic and postsynaptic sites at both GABA- and glutamate-mediated synapses in the CA1 area. It is a combination of these actions that results in depression of synaptically evoked discharge (Fig. 8). This is consistent with a multisite agent-specific mechanism of action for general anesthetics such as halothane (MacIver, 1997).

\section{REFERENCES}

Antkowiak B, Heck D (1997) Effects of the volatile anesthetic enflurane on spontaneous discharge rate and $\mathrm{GABA}_{\mathrm{A}}$-mediated inhibition of Purkinje cells in rat cerebellar slices. J Neurophysiol 77:2525-2538.

Banks MI, Pearce RA (1999) Dual actions of volatile anesthetics on $\mathrm{GABA}_{\mathrm{A}}$ IPSCs: dissociation of blocking and prolonging effects. Anesthesiology 90:120-134.

Carlen PL, Gurevich N, Davies MF, Blaxter TJ, O'Beirne M (1985) Enhanced neuronal $\mathrm{K}^{+}$conductance: a possible common mechanism for sedative-hypnotic drug action. Can J Physiol Pharmacol 63:831-837.

Daniell LC, Harris RA (1988) Neuronal intracellular calcium concentrations are altered by anesthetics: relationship to membrane fluidization. J Pharmacol Exp Ther 245:1-7.

Dodt HU, Zieglgansberger W (1990) Visualizing unstained neurons in living brain slices by infrared DIC-videomicroscopy. Brain Res 537:333-336.

Franks NP, Lieb WR (1994) Molecular and cellular mechanisms of general anaesthesia. Nature 367:607-614.

Freund TF, Buzsaki G (1996) Interneurons of the hippocampus. Hippocampus 6:347-470.

Hagan CE, Pearce RA, Trudell JR, MacIver MB (1998) Concentration measures of volatile anesthetics in the aqueous phase using calcium sensitive electrodes. J Neurosci Methods 81:177-184.

Harris BD, Moody EJ, Basile AS, Skolnick P (1994) Volatile anesthetics bidirectionally and stereospecifically modulate ligand binding to GABA receptors. Eur J Pharmacol 267:269-274.

Harris RA, Bruno P (1985) Effects of ethanol and other intoxicantanesthetics on voltage-dependent sodium channels of brain synaptosomes. J Pharmacol Exp Ther 232:401-406.

Huerta PT, Lisman JE (1995) Bidirectional synaptic plasticity induced by a single burst during cholinergic theta oscillation in CA1 in vitro. Neuron 15:1053-1063.

Jones MV, Harrison NL (1993) Effects of volatile anesthetics on the kinetics of inhibitory postsynaptic currents in cultured rat hippocampal neurons. J Neurophysiol 70:1339-1349.

Jones MV, Brooks PA, Harrison NL (1992) Enhancement of gammaaminobutyric acid-activated $\mathrm{Cl}^{-}$currents in cultured rat hippocampal neurones by three volatile anaesthetics. J Physiol (Lond) 449:279-293.

Kocsis B, Bragin A, Buzsaki G (1999) Interdependence of multiple theta generators in the hippocampus: a partial coherence analysis. J Neurosci 19:6200-6212.

Koltchine VV, Finn SE, Jenkins A, Nikolaeva N, Lin A, Harrison NL (1999) Agonist gating and isoflurane potentiation in the human gammaaminobutyric acid type A receptor determined by the volume of a second transmembrane domain residue. Mol Pharmacol 56:1087-1093.

Lacaille JC, Schwartzkroin PA (1988) Stratum lacunosum-moleculare interneurons of hippocampal CA1 region. I. Intracellular response characteristics, synaptic responses, and morphology. J Neurosci 8:1400-1410.

Lacaille JC, Mueller AL, Kunkel DD, Schwartzkroin PA (1987) Local circuit interactions between oriens/alveus interneurons and CA1 pyramidal cells in hippocampal slices: electrophysiology and morphology. J Neurosci 7:1979-1993.

Li X, Pearce RA (2000) Effects of halothane on GABA receptor kinetics: evidence for slowed agonist unbinding. J Neurosci 20:899-907.

Lukatch HS, MacIver MB (1997) Voltage-clamp analysis of halothane effects on GABA (A fast) and GABA (A slow) inhibitory currents. Brain Res 765:108-112.

MacDonald RL, Olsen RW (1994) GABA receptor channels. Annu Rev Neurosci 17:569-602.

MacIver MB (1997) General anesthetic actions on transmission at glutamate and GABA synapses. In: Anesthesia: biologic foundations (Yaksh TL, Lynch C, Zapol WM, Maze M, Biebuyck JF, Saidman LJ, eds), pp 277-286. Philadelphia: Lippincott-Raven.

MacIver MB, Kendig JJ (1991) Anesthetic effects on resting membrane potential are voltage-dependent and agent-specific. Anesthesiology 74:83-88.

MacIver MB, Roth SH (1988) Inhalation anaesthetics exhibit pathway- 
specific and differential actions on hippocampal synaptic responses in vitro. Br J Anaesth 60:680-691.

MacIver MB, Tauck DL, Kendig JJ (1989) General anaesthetic modification of synaptic facilitation and long-term potentiation in hippocampus. Br J Anaesth 62:301-310.

MacIver MB, Mikulec AA, Amagasu SM, Monroe FA (1996) Volatile anesthetics depress glutamate transmission via presynaptic actions. Anesthesiology 85:823-834.

Madison DV, Nicoll RA (1984) Control of the repetitive discharge of rat CA1 pyramidal neurones in vitro. J Physiol (Lond) 354:319-331.

Magyar J, Szabo G (1996) Effects of volatile anesthetics on the G-proteinregulated muscarinic potassium channel. Mol Pharmacol 50:1520-1528.

Mody I, Tanelian DL, MacIver MB (1991) Halothane enhances tonic neuronal inhibition by elevating intracellular calcium. Brain Res 538:319-323.

Mihic SJ, Ye Q, Wick MJ, Koltchine VV, Krasowski MD, Finn SE, Mascia MP, Valenzuela CF, Hanson KK, Greenblatt EP, Harris RA, Harrison NL' (1997) Sites of alcohol and volatile anaesthetic action on $\mathrm{GABA}_{\mathrm{A}}$ and glycine receptors. Nature 389:385-389.

Mikulec AA, Pittson S, Amagasu SM, Monroe FA, MacIver MB (1998) Halothane depresses action potential conduction in hippocampal axons. Brain Res 796:231-238.

Murugaiah KD, Hemmings HC (1998) Effects of intravenous general anesthetics on $[3 \mathrm{H}]$ GABA release from rat cortical synaptosomes. Anesthesiology 89:919-928.

Nakahiro M, Yeh JZ, Brunner E, Narahashi T (1989) General anesthetics modulate GABA receptor channel complex in rat dorsal root ganglion neurons. FASEB J 3:1850-1854.

Nicoll RA (1972) The effects of anaesthetics on synaptic excitation and inhibition in the olfactory bulb. J Physiol (Lond) 223:803-814.

Nicoll RA, Madison DV (1982) General anesthetics hyperpolarize neurons in the vertebrate central nervous system. Science 217:1055-1057.

Nicoll RA, Eccles JC, Oshima T, Rubia F (1975) Prolongation of hippocampal inhibitory postsynaptic potentials by barbiturates. Nature 258:625-627.

Nishikawa K, Kidokoro Y (1999) Halothane presynaptically depresses synaptic transmission in wild-type Drosophila larvae but not in halothane-resistant (har) mutants. Anesthesiology 90:1691-1697.

Nishikawa K, MacIver MB (2000) Excitatory synaptic transmission mediated by NMDA receptors is more sensitive to isoflurane than are nonNMDA receptor-mediated responses. Anesthesiology 92:228-236.

Olbrich HG, Braak H (1985) Ratio of pyramidal cells versus nonpyramidal cells in sector CA1 of the human Ammon's horn. Anat Embryol (Berl) 173:105-110.

Parra P, Gulyas AI, Miles R (1998) How many subtypes of inhibitory cells in the hippocampus? Neuron 20:983-993.

Patel AJ, Honore E, Lesage F, Fink M, Romey G, Lazdunski M (1999)
Inhalational anesthetics activate two-pore-domain background $\mathrm{K}+$ channels. Nat Neurosci 2:422-426.

Pearce RA (1993) Physiological evidence for two distinct $\mathrm{GAGA}_{\mathrm{A}}$ responses in rat hippocampus. Neuron 10:189-200.

Pearce RA (1996) Volatile anaesthetic enhancement of paired-pulse depression investigated in the rat hippocampus in vitro. J Physiol (Lond) 492:823-840.

Pearce RA, Stringer JL, Lothman EW (1989) Effect of volatile anesthetics on synaptic transmission in the rat hippocampus. Anesthesiology 71:591-598.

Perouansky M, Kirson ED, Yaari Y (1996) Halothane blocks synaptic excitation of inhibitory interneurons. Anesthesiology 85:1431-1438.

Pistis M, Belelli D, McGurk K, Peters JA, Lambert JJ (1999) Complementary regulation of anaesthetic activation of human (alpha6beta3gamma2L) and Drosophila (RDL) GABA receptors by a single amino acid residue. J Physiol (Lond) 515:3-18.

Regehr WG, Tank DW (1992) Calcium concentration dynamics produced by synaptic activation of CA1 hippocampal pyramidal cells. J Neurosci 12:4202-4223

Richards CD, White AE (1975) The actions of volatile anaesthetics on synaptic transmission in the dentate gyrus. J Physiol (Lond) 252:241-257.

Schlame M, Hemmings HC (1995) Inhibition by volatile anesthetics of endogenous glutamate release from synaptosomes by a presynaptic mechanism. Anesthesiology 82:1406-1416.

Sirois JE, Pancrazio JJ, Lynch C, Bayliss DA (1998) Multiple ionic mechanisms mediate inhibition of rat motoneurones by inhalation anaesthetics. J Physiol (Lond) 512:851-862.

Skaggs WE, McNaughton BL (1998) Spatial firing properties of hippocampal CA1 populations in an environment containing two visually identical regions. J Neurosci 18:8455-8466.

Tanelian DL, Kosek P, Mody I, MacIver MB (1993) The role of the GABAA receptor/chloride channel complex in anesthesia. Anesthesiology 78:757-776.

Thomas MJ, Watabe AM, Moody TD, Makhinson M, O'Dell TJ (1998) Postsynaptic complex spike bursting enables the induction of LTP by theta frequency synaptic stimulation. J Neurosci 18:7118-7126.

Wann KT, Southan AP (1992) The action of anaesthetics and high pressure on neuronal discharge patterns. Gen Pharmacol 23:993-1004.

Williams S, Samulack DD, Beaulieu C, Lacaille JC (1994) Membrane properties and synaptic responses whether interneurons located near the stratum lacunosum-moleculare/radiatum border of area CA1 in wholecell recordings from rat hippocampal slices. J Neurophysiol 71:2217-2235.

Yeckel MF, Berger TW (1998) Spatial distribution of potentiated synapses in hippocampus: dependence on cellular mechanisms and network properties. J Neurosci 18:438-450. 